Canadian

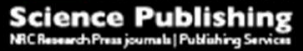

Botany

Botanique

\title{
Trabeculae and Al-accumulation in the wood cells of Melastomataceae species from Brazilian savanna.
}

\begin{tabular}{|r|l|}
\hline Journal: & Botany \\
\hline Manuscript ID & cjb-2016-0135.R2 \\
\hline Manuscript Type: & Article \\
\hline Date Submitted by the Author: & $11-$-Oct-2016 \\
\hline Complete List of Authors: & $\begin{array}{l}\text { Milanez, Camilla; Universidade Federal do Espirito Santo Centro de Ciencias } \\
\text { da Saude, Botânica } \\
\text { Marcati, Carmen Regina; Universidade Estadual Paulista Julio de Mesquita } \\
\text { Filho- Faculdade de Ciências Agronômicas, Botucatu, Ciência Florestal } \\
\text { Machado, Silvia; Universidade Estadual Paulista Julio de Mesquita Filho } \\
\text { Instituto de Biociencias Campus de Botucatu, Botânica }\end{array}$ \\
\hline Keyword: & aluminum, Cerrado, Melastomataceae, trabeculae \\
\hline &
\end{tabular}

SCHOLARONE ${ }^{\text {m }}$

Manuscripts 


\section{Original research}

Trabeculae and Al-accumulation in the wood cells of Melastomataceae species from Brazilian savanna

Camilla Rozindo Dias Milanez, Carmen Regina Marcati, and Silvia Rodrigues Machado

C. R. D. Milanez. UFES - Univ Federal do Espírito Santo, Departamento de Ciências

Biológicas, CEP 29075-910, Vitória, ES, Brazil. (Email: camilla.milanez@gmail.com)

C. R. Marcati. UNESP-Univ Estadual Paulista, Faculdade de Ciências Agronômicas, Departamento de Ciência Florestal, Botucatu, SP, CP 237, CEP 18603-970, Brazil. (Email: carmen@fca.unesp.br)

S. R. Machado. UNESP- Univ Estadual Paulista, Instituto de Biociências, Departamento de Botânica, Botucatu, SP, CP 510, CEP 18618-000, Brazil. (Email: smachado@ibb.unesp.br)

Corresponding author: Silvia Rodrigues Machado (email: smachado@ibb.unesp.br). 


\begin{abstract}
Melastomataceae is an important component of the Brazilian Cerrado flora inhabiting different environments from those with well-drained soil to swamp soil sites. Several members of this family are recognized as aluminum (Al)-accumulating. We studied the wood anatomy of six species of Melastomataceae (Miconia albicans, M. fallax, M. chamissois, M. ligustroides, Microlepis oleaefolia, Rhynchanthera dichotoma), growing in different environments of Cerrado, exploring the occurrence of trabeculae and Al-accumulation sites. We processed the material following usual techniques in wood anatomy and histochemistry. We used chrome azurol-S spot-test in fresh material to detect Al-accumulation. The common features were diffuse porosity, vessel elements with simple perforation plates and vestured pits, abundant parenchyma-like fiber bands and septate fibers, axial parenchyma scanty to vasicentric, and heterocellular rays. Presence of trabeculae in vessel elements, septa in parenchyma cells and aluminum in the G-layer of the gelatinous fiber walls, in the septa of fibers, in cambial initials and derivatives cell walls, and in the vacuole of ray cells are the first record for Melastomataceae. The results of this study indicate an additional role for gelatinous fibers in Al-accumulation and offer a new perspective on the Al-compartmentalization in the wood cells from Cerrado species.
\end{abstract}

Key words: aluminum; Cerrado; Melastomataceae; trabeculae 


\section{Introduction}

Brazilian savanna, called Cerrado, is characterized by dystrophic, acidic soils, which are extremely low in available nutrients and have high levels of soluble aluminum (Al) (Coutinho 2002). Cerrado flora comprises Al-accumulating and non-accumulating plants (Souza et al. 2015). Melastomataceae constitutes one of the most representative families from Cerrado flora (Mendonça et al. 1998), inhabiting different environments from those with welldrained soil to swamp soil sites. Several members of this family are recognized as aluminum (Al)-accumulating (Haridasan 1982; Jansen et al. 2002a, b; Watanabe et al. 1998; Watanabe et al. 2008). Recent studies have focused on the accumulation of Al mainly inside the leaf tissues (Jansen et al. 2002a, Maejima et al. 2014, Souza et al. 2015). However, information about the Al compartmentalization in secondary xylem cells is still lacking.

Remarkably, many species belonging to the Al-accumulating families have trabeculae in their secondary xylem cells, for example Rubiaceae, Proteaceae, Violaceae (Butterfield and Meylan 1979); Celastraceae, Thymeleaceae (Ohtani 1977), Asteraceae (Werker and Baas 1981), Elaeagnaceae (Sanio 1863 apud Werker and Baas 1981), Winteraceae (Bary 1877 apud Werker and Baas 1981) and Vochysiaceae (León 2005). For Melastomataceae (Al)accumulating members, trabeculae were not reported.

Trabeculae are intracellular structures connecting tangential walls of a cell through its lumen (Keith 1971; Ohtani 1977; Butterfield and Meylan 1979; Carlquist 2001) and consist of three cell wall layers, the central region being continuous and similar to the compound middle lamella. Trabeculae have been reported to occur in the secondary xylem and bark of many gymnosperms and in some angiosperms as already commented by Werker and Baas (1981), but not in Melastomataceae. 
The morphology of trabeculae is suggestive of incomplete cell divisions and they are therefore considered abnormalities that result from a disturbance in cambial activity (Larson 1994). However, the cause of trabeculae formation is still unknown. Hale (1923) suggested that the trabeculae are formed by the deposition of wall material around fungal hyphae. Other hypotheses (reviewed by Werker and Baas 1981; Grosser 1986) suggest that the activity of aphids and viruses as well as climatic factors such as frost, wounding and environmental stress in general, can induce the formation of trabeculae. Hypotheses regarding the effect of soil characteristics on trabeculae formation have not yet been put forward, although soil properties are known to indirectly influence wood formation (e.g. Yaltirik 1970; Dünisch and Bauch 1994; Villagra and Roig-Juñent 1997; Larson 1994).

In this study we describe the wood anatomy focusing on the trabeculae occurrence and Al-accumulation in wood cells of Melastomataceae species (Miconia albicans, M. fallax, M. chamissois, M. ligustroides, Microlepis oleaefolia, Rhynchanthera dichotoma) inhabiting different sites in the Brazilian Cerrado.

\section{Material and Methods}

\section{Study site and species}

The study was carried out in a fragment of Cerrado located within the municipality of Pratania, on the São Paulo State, Brazil (between $22^{\circ} 4848.8$ S, and $48^{\circ} 4433.7 \mathrm{~W}$ ).

We studied six species of Melastomataceae inhabiting different sites, ranging from well-drained to temporarily or permanently waterlogged soils, in the Brazilian Cerrado (Table 1): Miconia albicans (Sw.) Triana (treelet) and Miconia fallax DC. (shrub) from "cerrado sensu stricto" (strongly drained sites with deep water table and seasonal water deficit at topsoil level), Miconia chamissois Naudin (shrub), Miconia ligustroides (DC.) Naudin (shrub), Microlepis oleaefolia (DC.) Triana (shrub) from "riverine forest" (very wet alongside 
river course), and Rhynchanthera dichotoma DC. (subshrub) from "floodplain grasslands" (successive periods of soil-water logging and strong water deficit).

We deposited the Vouchers specimens in the Herbarium Irina Delanova Gemtchujnicov (BOTU), Instituto de Biociências, Univ Estadual Paulista (UNESP), Botucatu, São Paulo.

Chemical (supplementary table S1) and physical (supplementary table S2) soil characterization around the studied plants were analyzed. We collected soil samples from all sites at a depth of $0-20 \mathrm{~cm}$ and $20-40 \mathrm{~cm}$ (ten replicates each), close to the specimens studied. Soil samples were sent to the Physical and Fertility Soil Laboratory, Faculdade de Ciências Agronômicas, Univ Estadual Paulista (UNESP), Botucatu, São Paulo state, Brazil, for physical and chemical analysis. Soil analysis was carried out as per the procedures described by Raij et al. (2001). Air-dried soil samples were analyzed for available contents of phosphorus $(\mathrm{P})$; aluminum $(\mathrm{Al})$; acidity $(\mathrm{H}+\mathrm{Al})$; basic cations, including potassium $(\mathrm{K})$, calcium (Ca), and magnesium (Mg); sum of the bases $\mathrm{Ca}, \mathrm{Mg}$ and $\mathrm{K}(\mathrm{SB})$; $\mathrm{pH}$; base saturation $(\mathrm{V} \%)$. The cation exchange capacity (CEC) was analyzed using buffered SMP solution $(\mathrm{pH}=$ 7) (Shoemaker et al., 1961). The total organic carbon (OM) was analyzed using the Colorimetric Method (Walkley and Black, 1934; modified).

\section{Sampling and anatomical procedure}

We obtained samples from the basal portion of main stems of the treelets, shrubby, and sub shrubby species. Three individuals were sampled for each species. We fixed the samples in FAA50 (formalin-aceto-alcohol 50) (Johansen 1940) and stored in 70\% ethanol and glycerin (1:1). We cut wood samples using a sliding microtome, and the sections $(15 \mu \mathrm{m})$ were double stained with 1\% aqueous solution of safranin and astra blue (Bukatsch 1972), and mounted permanently in Permount synthetic medium. 
For histochemistry, we collected and sectioned fresh material using a sliding microtome and treated the sections with ferric chloride for identification of phenolic compounds (Johansen 1940), potassium iodide for starch grains (Johansen 1940), ruthenium red for polysaccharides (Jensen 1962), Sudan IV for lipids (Johansen 1940), and acidified Floroglucine for lignin (Sass 1951). We detected the presence of aluminum with chrome azurol-S reagent (Kukachka and Miller 1980) using fresh sample sections.

Maceration was obtained using a mixture of equal volumes of glacial acetic acid and hydrogen peroxide (30 volumes) at $60{ }^{\circ} \mathrm{C}$ (Franklin 1945) for 48 hours. The material was stained with a solution of astra blue and safranin 1\% (Bukatsch 1972) and aqueous safranin 1\% (Johansen 1940), and mounted in glycerin.

Quantitative data are based on 30 counts per species, and was performed in a semiautomatic image analyzer (Zeiss), using Zeiss AxioVision 3.1 software. Wood description followed IAWA Committee (1989).

\section{Results}

The wood is diffuse porous (Fig. 1A-F). The vessels are solitary and multiples of 2-6 (Fig. 1A-F) (Table 2); clusters rarely; solitary vessel outline angular in M. chamissois, $M$. oleaefolia and R. dichotoma; circular to oval in M. albicans, M. falax and M. ligustroides; tails in one or both element vessel tips; simple perforation plates (Fig. 2A); intervessel pits alternate, vestured (Fig. 2B-C), circular in all Miconia analysed and polygonal in $M$. oleaefolia and $R$. dichotoma (Fig. 2A); vessel-ray pits with distinct borders, similar to intervessel in size and shape throughout the ray in all Miconia analysed (Fig. 2D), with much reduced borders to apparently simple in $M$. oleaefolia (Fig. 2E), pits horizontal in $R$. dichotoma (Fig. 2F). Septa of pectic-cellulosic nature frequent in vessels of Miconia (Fig. 3A- 
D) and R. dichotoma. Trabeculae were observed throughout in vessel elements of M. albicans (Fig. 4A), M. fallax (Fig. 4B-D) and M. ligustroides (Fig. 4E).

Fibers have simple to minutely bordered pits in both radial and tangential walls (Fig. 5A); thin- to thick-walled (Fig. 1A-F); abundant parenchyma-like fiber bands in Miconia (Fig. 1A, 1C-E) and R. dichotoma (Fig. 1F) and in less amount in M. oleaefolia (Fig. 1B). Septate fibers (Fig. 5A) present in all species. Gelatinous fibers (Fig. 1A-D, 1F, 5B) present in all species, except in M. ligustroides and M. fallax.

Axial parenchyma is scanty to vasicentric (Fig. 1A-F, 5C), 2-6 cells per parenchyma strand in M. albicans and M. chamissois, 2-4 cells in M. fallax and M. ligustroides, 2-9 cells in M. oleaefolia and R. dichotoma. Septa of pectic-cellulosic nature frequent in Miconia (Fig. 5D) and R. dichotoma (Fig. 5E).

Rays are exclusively uniseriate in Miconia species (Fig. 6A) and R. dichotoma, ray width 1-4 cells in M. oleaefolia (Fig. 6B); heterocellular, with procumbent, square and upright cells intermixed in M. albicans (Fig. 6C), and square and upright cells intermixed in the other species (Fig. 6D). Septa present in M. chamissois (Fig. 6E).

Starch grains occur in ray cells of Miconia (Fig. 7A), in septate fibers of M. albicans (Fig. 7B) and M. chamissois, and in ray and axial parenchyma cells of M. fallax.

Phenolic compounds in ray cells of M. albicans and M. oleaefolia and inside septate fibers in M. albicans (Fig. 7C-D) and M. fallax. Mucilage in ray cells of M. albicans. Oil in ray cells of M. oleaefolia.

Druses occur in vessel elements of M. chamissois (Fig. 7E-F) and in idioblasts located in the margin of the rays in M. oleaefolia (Fig. 7G-H).

Aluminum was detected in the G-layer of the gelatinous fiber walls in M. albicans (Fig. 8A), in the septa of fibers in M. albicans, M. fallax and M. ligustroides (Fig. 8B), in the vacuole of ray cells in M. ligustroides (Fig. 8C), and in cambial cell walls as well as in the 
wall of the differentiating vessel elements in M. albicans, M. fallax and M. ligustroides (Fig. 8D-G).

\section{Discussion}

In this research we studied the wood anatomy of six species of Melastomataceae growing in the Brazilian Cerrado focusing on the presence of trabeculae in vessel elements, and Al-accumulating in different wood cells.

The general wood anatomy of the studied species including vessels arranged in a diffuse-porous pattern, vessel elements with simple perforation plates, intervessel pits alternate and vestured, parenchyma-like fibre bands and septate fibers abundant, scanty to vasicentric axial parenchyma and heterocellular rays corroborates with previous descriptions for Melastomataceae (Metcalfe and Chalk 1950, 1983; Ter Welle and Koek-Noorman 1981; Medeiros and Morretes 1994; Marcon and Costa 2000; Sonsin et al. 2014; Silva et al. 2015). However, in this study we observed the occurrence of trabeculae in vessel elements, and Alaccumulation in septa of fibers, in the G-layer of the gelatinous fibre walls, in the vacuole of ray cells, in the cambial cell walls, and in the walls of immature vessel elements. These features constitute new observations for Melastomataceae species.

Growth rings in the wood of Melastomataceae species in this study might be related to the environmental conditions as already reported for other species (Alves and AngyalossyAlfonso 2000; Marcati et al. 2006; Lisi et al. 2008). We believe that the absence of growth rings in $R$. dichotoma plants that grow in a swampy soil site might be related to the constant water availability in the soil while the fluctuation of water availability in the soil where the other species grow would reflect in growth markers in the wood.

Abundant parenchyma-like fibre bands were observed in all examined Miconia species and Rhynchanthera dichotoma, and in lesser amount in Microlepis oleaefolia. These fibers are 
septate, have thinner walls and larger lumen and have been reported for other Melastomataceae species (Détienne and Jacquet 1983, Marcon and Costa 2000, Sonsin et al. 2014, Silva et al. 2015). The small amount of axial parenchyma and the higher amount of the parenchyma-like fibers rich in starch grains in the studied species support the hypothesis that the parenchyma-like characteristics in fibers might represent a way in which a wood ground tissue functioning like that of parenchyma can be achieved (Spackman and Swamy 1949, Carlquist 2001). In addition to the septa in fibers, we also observed septa in axial and ray parenchyma cells, which constitute the first report in Melastomataceae species.

In Miconia species we observed intracellular (inside the vacuole of rays) and tissue compartmentalization (G-layer, septa of cells, cambial cell walls, and differentiating vessel elements) of the Al by using chrome azurol-S reagent as a spot test. Although other more precise analytical techniques, such as energy-dispersive microanalysis (EDXMA), and lowenergy X-ray fluorescence spectro-microscopy (LEXRF), have been employed to detect the actual Al localization (Tolrà et al. 2011), we have chosen to use chrome azurol-S reagent because it is a practical, quick and cheap method commonly used in wood studies (Kukachka and Miller 1980). This method gave us an indication of Al accumulation by producing a positive staining reaction. This Al-compartmentalization should be an important strategy of the plants to avoid Al-toxicity (Foy et al. 1978; Watanabe and Osaki 2002, Maejima et al. 2014); however, a beneficial effect of aluminum has been reported on the growth of plant species that are well adapted to tropical acid soils (Haridasan 1988; Osaki et al. 1997, Watanabe and Osaki 2002, Watanabe et al. 2005) by increasing nutrients concentrations, mainly phosphorus, in the plant tissues (Osaki et al. 1997). In Miconia albicans occurring in acid latosols of the Cerrado from central Brazil, Haridasan (1988) reported an enhanced growth when its roots were exposed to distilled water containing aluminum. The species of Miconia studied here are adapted to acid soils from Cerrado, they accumulate Al 
intracellularly and in different wood tissues, and this might benefit its growth in Cerrado acid soils.

Although some authors have reported that the Al may be associated with high content of phenolics in the vacuoles (Nagy et al. 2004) and with oxalate forming Al-oxalate complexes (Watanabe et al. 1998, Maejima et al. 2014; Schmidt et al. 2016), in this study this association is unclear. The aluminum, but not phenolics, was detected in Miconia ligustroides while phenolics, but not aluminum, were detected in Microlepis oleaefolia. It is remarkable that druses of calcium oxalate were present in those species (Miconia chamissois, Microlepis oleaefolia) lacking Al- accumulation. Implications of organic (oils, mucilage, phenolics) and inorganic substances (oxalate crystals) on internal Al-tolerance mechanisms of Melastomataceae deserve further studies.

Examining the trabeculae structure in the vessel elements of Miconia (M. albicans, M. fallax, and M. ligustroides), we found a strong resemblance in morphology with the Alaffected cell walls of the meristematic cells in the root of Triticum turgidum (Frantzios et al. 2001). In these cells the aluminum affected the organization of the microtubules resulting in the formation of binucleated cells with incomplete walls. It is important to highlight that in this study the aluminum was detected in the meristematic cell walls (cambial cells) as well as in the wall of the differentiating vessel elements in Miconia (M. albicans, M. fallax, and M. ligustroides) where the trabeculae were detected. The occurrence of trabeculae in the wood have been attributed to irregularities in the normal periclinal and anticlinal divisions of fusiform initials and differentiation of their derivatives (Larson 1994). Therefore, if our interpretation is correct, we suggest that the trabeculae are a result of the irregular divisions of the cambial initials caused by aluminum accumulation.

It is remarkable the high amount of gelatinous fibers in the wood of Miconia albicans, M. chamissois, Microlepis oleaefolia and Rhynchanthera dichotoma. Gelatinous fibersfibers 
are generally related to the development of tension wood (Esau 1977; Fahn 1990), and also to the storage of water because of their highly hygroscopic internal walls (Paviani 1978). Interestingly in our study these fibers also act as an important compartment of Al storage. Aluminum has been reported to be accumulated in the cell walls (Rengel 1996), and in the vacuoles (Ma et al. 2001), and this study is the first report of Al- accumulation in G-layer of gelatinous fibers.

This study brings novel data for Melastomataceae wood by confirming the presence of trabeculae in vessel elements and septa in parenchyma cells. Additionally, it suggests an additional role for gelatinous fibers in aluminum accumulation and offers a new perspective on the aluminum compartmentalization in the wood cells from Cerrado species.

\section{Acknowledgements}

This research was supported by São Paulo State Foundation for Science - Fapesp (Proc. 00/12469-3, 03/ 00958-8, 15/14954-1), and the Brazilian National Council for Science CNPq (Proc. 301464/2008-1) for grant to S.R. Machado. Authors contributed equally to this work.

\section{References}

Alves, E.S., and Angyalossy-Alfonso, V. 2000 Ecological trends in the wood anatomy of some Brazilian species. 1. Growth rings and vessels. IAWA J. 21(1): 3-30.

Bukatsch, F. 1972. Bemerkungen zur Doppelfärbung Astrablau-Safranin. Mikrokosmos, 61(8): 255 .

Butterfield, B.G., and Meylan, B.A. 1979. Observations of trabeculae in New Zealand hardwoods. Wood Sci. Technol. 13(1): 59-65. 
Carlquist, S. 1977. Ecological factors in wood evolution: a floristic approach. Am. J. Bot. 64(7): 887-896. Available from http://www.jstor.org/stable/2442382.

Carlquist, S. 2001. Comparative wood anatomy: systematic, ecological and evolutionary aspects of dicotyledon wood. $2^{\text {nd }}$ ed. Springer-Verlag, Berlin.

Coutinho, M.M. 2002. O bioma cerrado. Edited by H.L. Klein. Editora Unesp, São Paulo, pp. $77-92$.

Détienne, P., and Jacquet, P. 1983. Atlas d'identification des bois de l'Amazonie et régions voisines. Nogent-sur-Mane, Centro Technique Forestier Tropical.

Dünisch, O., and Bauch, J. 1994. Influence of mineral elements on wood formation of old growth spruce (Picea abies [L.] Karst.). Holzforschung 48(s1): 5-14.

Esau, K. 1977. Plant anatomy. Jonh Wiley \& Sons, Inc., New York.

Fahn, A. 1990. Plant Anatomy, $4^{\text {th }}$ ed. Pergamon Press, Oxford.

Foy, C.D., Chaney, R.L., and White, M.C. 1978. The physiology of metal toxicity in plants. Ann. Rev. Plant Phys. 29: 511-566. doi: 10.1146/annurev.pp.29.060178.002455.

Franklin, G.L. 1945. Preparation of thin sections of synthetic resins and wood-resin composites, and a new macerating method for wood. Nature 155: 51-51. doi:10.1038/155051a0.

Frantzios, G., Galatis, B., and Apostolakos, P. 2001. Aluminum effects on microtubule organization in dividing root-tip cells of Triticum turgidum. II. Cytokinetic cells. J. Plant Res. 114(2): 157-170. doi:10.1007/PL00013979.

Grosser, D. 1986. On the occurrence of trabeculae with special consideration of diseased trees. IAWA J. 7(4): 319-341. doi:10.1163/22941932-90001003.

Hale, J.D. 1923. Trabeculae of Sanio - their origin and distribution. Science 57: 155-155.

Haridasan, M. 1982. Aluminum accumulation by some cerrado native species of central Brazil. Plant Soil 65(2): 265-273. doi:10.1007/BF02374657. 
Haridasan, M. 1988. Performance of Miconia albicans (Sw.) Triana, an aluminium accumulating species, in acidic and calcareous soils. Communications in Soil Science and Plant Analysis 19(7-12): 1091-1103.

IAWA Committee. 1989. IAWA list of microscopic features for hardwood identification. IAWA J. 10(2): 219-332.

Jansen, S., Watanabe, T., and Smets, E. 2002a. Aluminum accumulation in leaves of 127 species in Melastomataceae, with comments on the order Myrtales. Ann. Bot. 90(1): 53-64. doi: $10.1093 / \mathrm{aob} / \mathrm{mcf1} 42$.

Jansen, S., Broadley, M.R., Robbrecht, E., and Smets, E. 2002.b. Aluminum hyperaccumulation in Angiosperms: a review of its phylogenetic significance. Bot. Rev. 68(2): $235-269$.

Jensen, W.A. 1962. Botanical histochemistry; principles and practice. H. Freeman \& Co., San Francisco.

Johansen, D.A. 1940. Plant microtechnique. McGraw-Hill Co., New York.

Keith, C.T. 1971. Observations on the anatomy and fine structure of the trabeculae of Sanio. IAWA J. 3(1): 3-11.

Kukachka, B.F., and Miller, R.B. 1980. A chemical spot-test for aluminum and its value in wood identification. IAWA J. 1(3): 104-109. doi: 10.1163/22941932-90000699.

Larson, P.R. 1994. The vascular cambium: development and structure. Springer-Verlag, Berlin.

León, W. J. 2005. Estudio anatómico de la madera de 21 especies del género Vochysia Poir. (Vochysiaceae). Acta Bot. Venez. 28(2): 213-232. Available fromhttp://www.scielo.org.ve/scielo.php?script=sci_arttext\&pid=S008459062005000200004. 
Lisi, C.S., Tomazello Filho, M., and Botosso, P.C. 2008.Tree-ring formation, radial increment periodicity, and phenology of tree species from a seasonal semi-deciduous forest in Southeast Brazil. IAWA J. 29(2): 189-207. doi: 10.1163/22941932-90000179.

Ma, J.F., Ryan, P.R., and Delhaize, E. 2001. Aluminum tolerance in plants and the complexing role of organic acids. Trends Plant Sci. 6(6): 273-278. doi: 10.1016/S13601385(01)01961-6.

Maejima, E., Watanabe, T., Osaki, M, and Wagatsuma, T. 2014. Phosphorus deficiency enhances aluminum tolerance of rice (Oryza sativa) by changing the physicochemical characteristics of root plasma membranes and cell walls. J. Plant Physiol. 171(2): 9-15.

Marcati, C.R., Oliveira, J.O., and Machado, S.R. 2006. Growth rings in cerrado woody species: occurrence and anatomical markers. Biota Neotrop. 6(3): 1-31. doi: $10.1590 /$ S1676-06032006000300001.

Marcon, M.L., and Costa C.G. 2000. Anatomia da madeira de quatro espécies do gênero Miconia Ruiz \& Pavón (Melastomataceae). Rodriguésia 51(78/79): 5-20. Available from http://rodriguesia.jbrj.gov.br/FASCICULOS/rodrig51/2_mico.pdf.

Medeiros, J.D., and Morretes, B.L. 1994. Anatomia da madeira e da casca de Miconia cabuçu Hoehne (Melastomataceae). Insula 23: 15-34. Available from https://periodicos.ufsc.br/index.php/insula/article/view/22063/19997.

Mendonça, R.C.; Felfili, J.M.; Walter, B.M.T.; Silva Júnior, M.C.; Rezende, A.V.; Filgueiras, T.S., and Nogueira, P.E. 1998. Flora vascular do cerrado, pp. 287- 556. In: M.S. and S.P. Almeida (Eds.) Cerrado: ambiente e flora. Embrapa-CPAC. Planaltina, DF.

Metcalfe, C.R., and Chalk, L. 1950. Anatomy of the dicotyledons. Claredon Press, Oxford.

Metcalfe, C.R., and Chalk, L. 1983. Anatomy of the dicotyledons; wood structure and conclusion of the general introduction $2^{\text {nd }}$ ed. Claredon Press, Oxford. 
Nagy, N.E., Dalen, L.R., Jones, D.L., Swensen, B., Fossdal, C.G., and Eldhuset, T.D. 2004. Cytologycal an enzymatic responses to aluminum stress in root tips of Norway spruce seedlings. New Phytol. 163(3): 595-607. doi:10.1111/j.1469-8137.2004.01134.x.

Ohtani, J. 1977. An observation of trabeculae in some dicotyledons woods using scanning electron microscopy. Res. Bull. Coll. Exp. For., Hokkaido Univ. 34(1): 69-78. Available from http://hdl.handle.net/2115/20974.

Osaki, M., Watanabe, T., and Tadano, T. 1997. Beneficial effect of aluminum on growth of plants adapted to low pH soils. Soil Sci. Plant Nutr. 43 (3): 551-563.

Paviani, T. I. 1974. Sobre a ocorrência de fibras gelatinosas em Plathymenia reticulata Benth. Cien. Cult. 26(8): 783-786.

Raij, B., van Andrade, J.C., Cantarella, H., Quaggio, J.A., 2001. Análise química para avaliação da fertilidade do solo. Instituto Agronômico, Campinas.

Rengel, Z. 1996. Uptake of aluminium by plant cells. New Phytol. 134(3): 389-406. doi: 10.1111/j.1469-8137.1996.tb04356.x.

Sass, J.E. 1951. Botanical microtechnique. $2^{\text {nd }}$. ed. Iowa State College, Iowa.

Silva, M.S., Santos, F.A.R., Silva, C.R.A.S., Santos, N.C., and Silva, L.B. 2015. Systematic wood anatomy of Huberia, Miconia and Tibouchina (Melastomataceae). IAWA J. 36(3): 326-337. doi: 10.1163/22941932-20150103.

Schmitt, M., Boras, S., Tjoa, A., Watanabe, T., and Jansen, S. 2016. Aluminium accumulation and intra-tree distribution patterns in three Arbor aluminosa (Symplocos) species from Central Sulawesi. PLoS ONE. doi:10.1371/journal.pone.0149078.

Shoemaker, H.E., McLean, E.O., Pratt, P.F. 1961. Buffer methods for determining the lime requirement of soils with appreciable amounts of extractable aluminum. Soil Sci. Soc. Am. Proc. 25: 274-277. 
Sonsin, J.O., Gasson, P.E., Machado, S.R., Caum, C., and Marcati C.R. 2014. Atlas da diversidade de madeiras do cerrado Paulista. $1^{\text {st }}$ ed. FEPAF, Botucatu.

Souza, M.C., Bueno, P.C.P., Morellato L.P.C., and Habermann, G. 2015. Ecological strategies of Al-accumulating and non-accumulating functional groups from cerrado sensu stricto. An. Acad. Bras. Ciênc. 87(2): 813-823. doi: 10.1590/0001-3765201520140222.

Spackman, W., and Swamy, B.G.L. 1949. The nature and occurrence of septate fibers in dicotyledons. Am. J. Bot. 36: 804.

Ter Welle, B.J.H., and Koek-Noorman, J. 1981. Wood anatomy of the neotropical Melastomataceae. $\quad$ Blumea 27(2): 335-394. Available from http://repository.naturalis.nl/record/525630.

Tolrà, R., Vogel-Mikus, K., Hajiboland, R., Kump, P., Pongrac, P., Kaulich, B., Gianoncelli, A., Babin, V., Barcelo, J., Regvar, M., and Poschenrieder, C. 2011. Localization of aluminum in tea (Camellia sinensis) leaves using low energy X-ray fluorescence spectromicroscopy. J. Plant Res. 124(1):165-172. doi: 10.1007/s10265-010-0344-3.

Villagra, E.P., and Roig-Juñent, F.A. 1997. Wood structure of Prosopis alpataco y P. argentina growing under different edaphic conditions. IAWA J. 18(1): 37-51. doi: $10.1163 / 22941932-90001458$.

Walkley, A., Black, I.A. 1934. An examination of Degtjareff method for determining soil organic matter and a proposed modification of the chromic acid titration method. Soil Sci. (Balt.) 37: 29-38.

Watanabe, T., Osaki, M., Yoshihara, T., and Tadano, T. 1998. Distribution and chemical speciation of aluminum in the Al accumulator plant, Melastoma malabathricum L. Plant Soil 201(2): 165-173. 
Watanabe, T., and Osaki, M. 2002. Mechanisms of adaptation to high aluminum condition in native plant species growing in acid soils: a review. Commun. Soil Sci. Plant Anal., 33(7\&8): 1247-1260.doi: 10.1081/CSS-120003885.

Watanabe, T., Jansen, S., and Osaki, M. 2005.The beneficial effect of aluminum and the role of citrate in Al accumulation in Melastoma malabathricum. New Phytol. 165(3): 773-780. doi: 10.1111/j.1469-8137.2004.01261.x.

Watanabe, T., Misawa, S., Hiradate, S., and Osaki, M. 2008. Characterization of root mucilage from Melastoma malabathricum, with emphasis on its role in aluminum accumulation. New Phytol. 178(3): 581-589.

Werker, E., and Baas, P. 1981. Trabeculae of Sanio in secondary tissues of Inula viscosa (L.) Desf. and Salvia fruticosa Mill. IAWA J. 2(2-3): 69-76. doi: 10.1163/22941932-90000817. Yaltirik, F. 1970. Comparison of anatomical characteristics of wood in Turkish maples with relation to the humidity of the sites. J. Wood Sci. 5(25): 43-48. Available from http://www.cabdirect.org/abstracts/19700607078.html;jsessionid=F25FBA74973CC7C0C C70C2017522428F. 
Table 1 Studied Melastomataceae species from Brazilian savanna located at Pratânia, São Paulo state.

\begin{tabular}{lccc}
\hline Species & Environment & Heigth & Average sample diameter \\
& & $(\mathbf{m})$ & $\mathbf{( c m )}$ \\
\hline Miconia albicans & cerrado sensu stricto & $2,5-2,8$ & 4,0 \\
Miconia chamissois & riverine forest & $2,0-2,5$ & 2,5 \\
Miconia fallax & cerrado sensu stricto & $1,5-1,7$ & 2,0 \\
Miconia ligustroides & riverine forest & $2,0-2,5$ & 3,0 \\
Microlepis oleaefolia & near riverine forest & $1,5-1,7$ & 2,0 \\
Rhynchanthera dichotoma & floodplain grasslands & $0,5-0,7$ & 0,7 \\
\hline
\end{tabular}


Table 2. Percentage of vessel grouping in the Melastomataceae species studied.

\begin{tabular}{lcccc}
\hline \multicolumn{1}{c}{ Species } & Solitary & Multiple-2 & Multiple-3 & Multiple-4+ \\
\hline Miconia albicans & 47,0 & 35,3 & 11,6 & 6,1 \\
\hline Miconia chamissois & 52,6 & 31,7 & 9,5 & 6,2 \\
\hline Miconia fallax & 59,7 & 26,6 & 8,4 & 5,3 \\
\hline Miconia ligustroides & 60,5 & 30,7 & 6,5 & 2,3 \\
\hline Microlepis oleaefolia & 76,8 & 15,1 & 5,1 & 3,0 \\
\hline Rhynchanthera dichotoma & 78,4 & 17,0 & 3,1 & 1,5 \\
\hline
\end{tabular}




\section{Figure captions}

Fig. 1. Transverse sections of Melastomataceae wood. (A) Miconia ligustroides. (B) Microlepis oleaefolia. (C) Miconia chamissois. (D) Miconia albicans. (E) Miconia fallax. (F) Rhynchanthera dichotoma. The arrows indicate growth ring markers. GF = gelatinous fibers. Bars $=200 \mu \mathrm{m}$.

Fig. 2. Vessel characteristics of Melastomataceae species. (A) Vessel element showing simple perforation plates and polygonal intervessel pits in Rhynchanthera dichotoma. (B-C) Vestured pits by scanning electron microscope. (B) Miconia albicans. (C) Microlepis oleaefolia. (D-F) Vessel-ray pits. (D) Miconia chamissois. (E) Microlepis oleaefolia. (F) Rhynchanthera dichotoma . Bars $=$ (A) $50 \mu \mathrm{m} ;(\mathrm{B}-\mathrm{C}) 5 \mu \mathrm{m} ;(\mathrm{D}-\mathrm{F}) 25 \mu \mathrm{m}$.

Fig. 3. Septae in vessels. The arrows indicate septae. (A-B) Miconia albicans. (C) Miconia chamissois. (D) Miconia fallax. Bars = (A, C) $50 \mu \mathrm{m} ;(\mathrm{B}, \mathrm{D}) 25 \mu \mathrm{m}$.

Fig. 4. Trabeculae in vessel elements in Melastomataceae species. Macerated wood. (A) Miconia albicans. (B-D) Miconia fallax. (E) Miconia ligustroides. The arrows indicate trabeculae. Bars $=(A-C) 50 \mu \mathrm{m}$; (D-E) $25 \mu \mathrm{m}$.

Fig. 5. Wood features of Melastomataceae species. (A) Simple to minutely bordered pits in radial wall and septate fibers in Miconia albicans. (B) Gelatinous fibers in Rhynchanthera dichotoma (C) Scanty axial parenchyma around vessel (V) in Miconia albicans (D-E) Septa (arrows) in axial parenchyma. (D) Miconia albicans. (E) Rhynchanthera dichotoma. Bars = (A, B, D, E) $25 \mu \mathrm{m}$; (C) $50 \mu \mathrm{m}$.

Fig. 6. Rays of Melastomataceae species. (A-B) Tangential sections. (A) Rays exclusively uniseriate in Miconia albicans. (B) Ray 1-3 cells width in Microlepis oleaefolia. (C-D) Heterocellular rays in radial sections. (C) Procumbent, square and upright cells intermixed in Miconia albicans. (D) Square and upright cells in Miconia fallax. (E) Septae in ray cells and 
fiber in Miconia chamissois in tangential section. Bars $=(A, B, D) 200 \mu \mathrm{m}$; (C) $100 \mu \mathrm{m}$; (E) $50 \mu \mathrm{m}$.

Fig. 7. Inclusions in wood cells of Melastomataceae species. (A-B) Starch grains (arrows) in wood cells of Miconia albicans in radial and tangential section, respectively. (A) In ray cells (B) In septate fibers. (C-D) Phenolic compounds (arrows) inside septate fibers of Miconia albicans in transverse and radial section, respectively. (E-H) Druses (arrows) in wood cells. (E-F) Inside vessel element in Miconia chamissois in transverse section, and in dissociate cell, respectively. $(\mathrm{G}-\mathrm{H})$ In the margin of the ray in Microlepis oleaefolia in transverse and tangential section, respectively. $\mathrm{RA}=$ ray. $\mathrm{Bars}=(\mathrm{A}, \mathrm{B}, \mathrm{D}, \mathrm{E}, \mathrm{G}, \mathrm{H}) 50 \mu \mathrm{m} ;$ (C) $25 \mu \mathrm{m}$; (F) $100 \mu \mathrm{m}$.

Fig. 8. Spot-test using chrome azurol-S reagent to detect aluminium accumulation, blue color for positive response. (A) In the inner wall of gelatinous fibers (arrows) of Miconia albicans. (B) In the septa of fibers (arrows) of Miconia ligustroides. (C) In the vacuoles of ray cells (asterisks) of Miconia ligustroides. (D-G) In the cambial cell walls and in the walls of differentiating cells. (D) Miconia albicans. (E) Miconia fallax. (F-G) Miconia ligustroides. $\mathrm{CZ}=$ cambial zone; $\mathrm{DC}=$ differentiating xylem cells; ${ }^{*}=$ differentiating vessels. Bars $=(\mathrm{A}$, E) $25 \mu \mathrm{m} ;(\mathrm{B}, \mathrm{D}, \mathrm{F}) 100 \mu \mathrm{m} ;(\mathrm{C}, \mathrm{G}) 50 \mu \mathrm{m}$. 


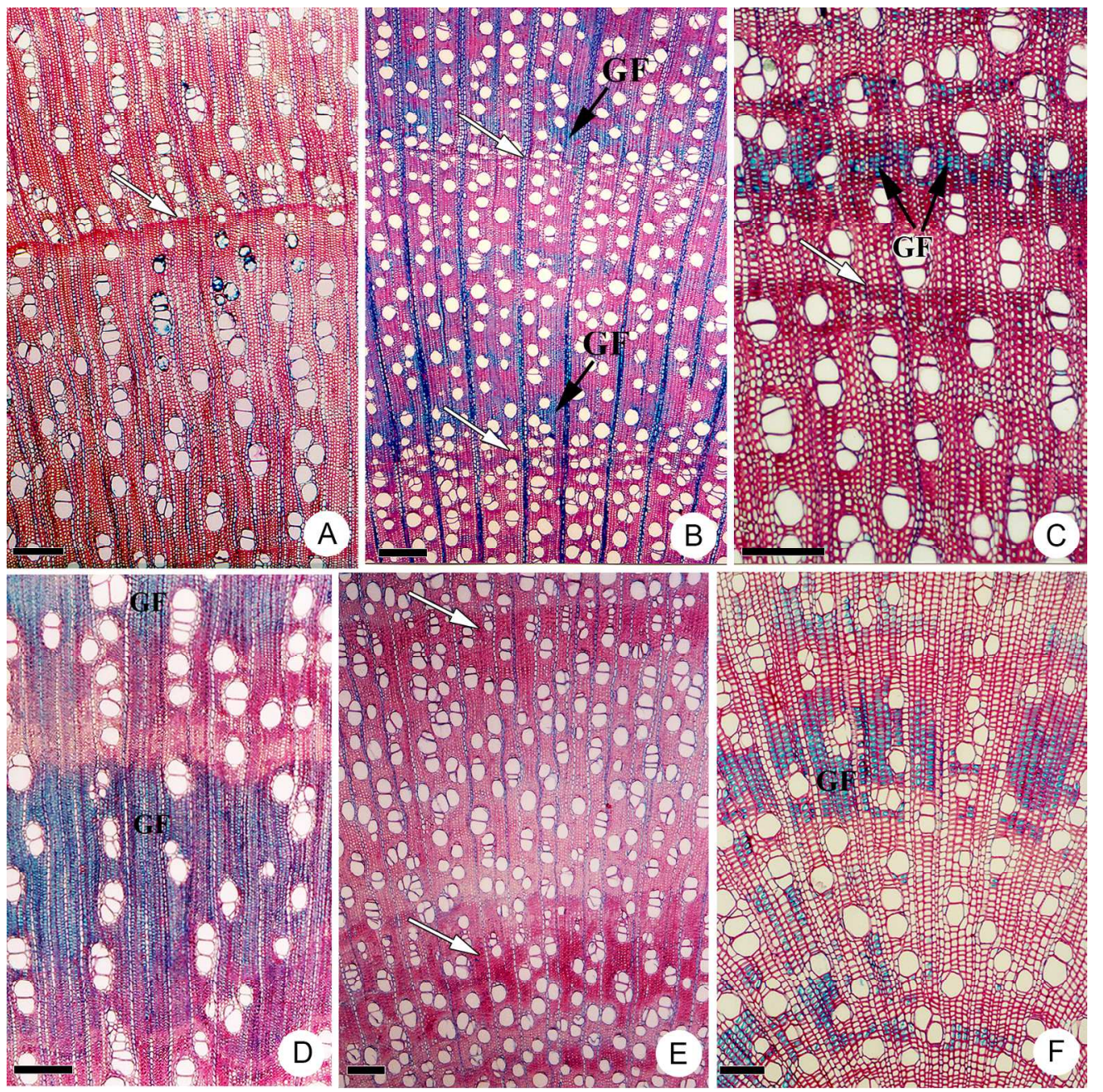

Fig. 1. Transverse sections of Melastomataceae wood. (A) Miconia ligustroides. (B) Microlepis oleaefolia. (C) Miconia chamissois. (D) Miconia albicans. (E) Miconia fallax. (F) Rhynchanthera dichotoma. The arrows indicate growth ring markers. GF = gelatinous fibers. Bars $=200 \mu \mathrm{m}$. 

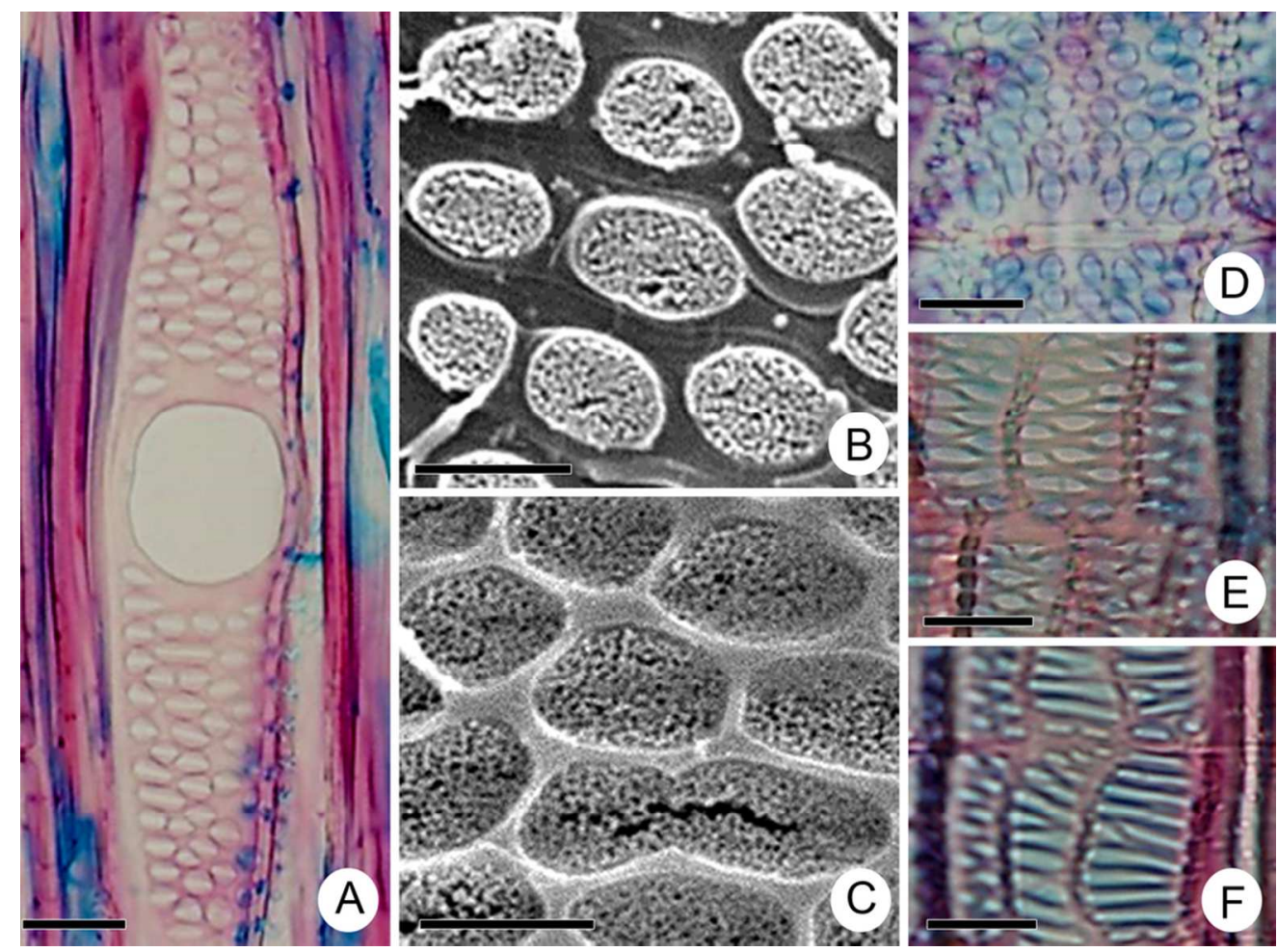

Fig. 2. Vessel characteristics of Melastomataceae species. (A) Vessel element showing simple perforation plates and polygonal intervessel pits in Rhynchanthera dichotoma. (B-C) Vestured pits by scanning electron microscope. (B) Miconia albicans. (C) Microlepis oleaefolia. (D-F) Vessel-ray pits. (D) Miconia chamissois.

(E) Microlepis oleaefolia. (F) Rhynchanthera dichotoma. Bars = (A) $50 \mu \mathrm{m} ;(B-C) 5 \mu \mathrm{m}$; (D-F) $25 \mu \mathrm{m}$.

$89 \times 66 \mathrm{~mm}(300 \times 300 \mathrm{DPI})$ 

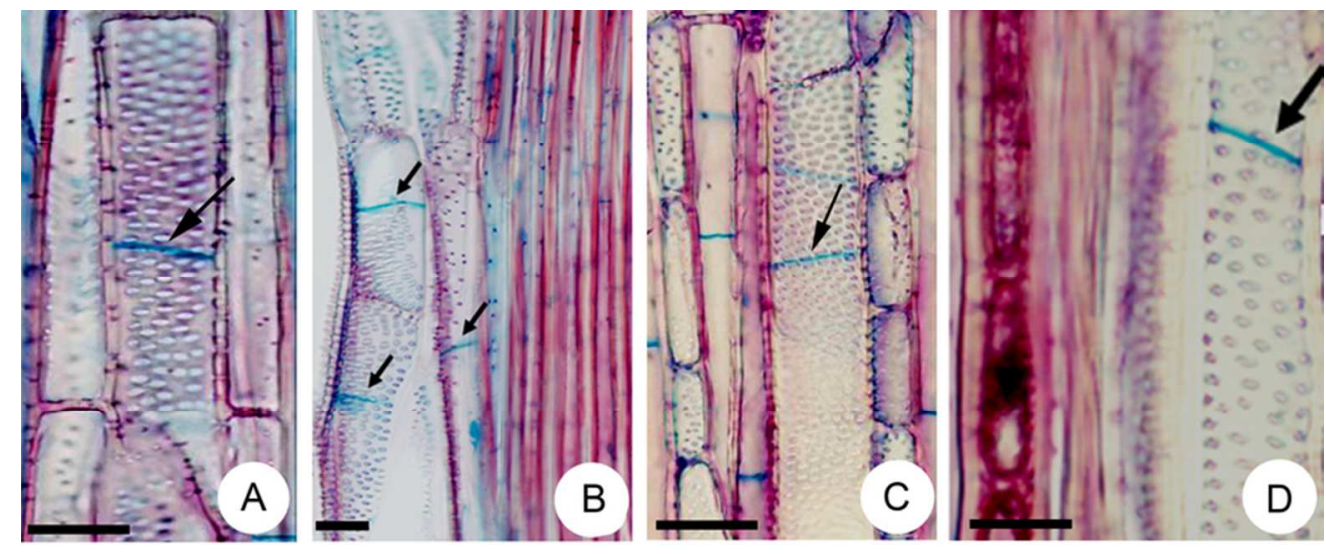

Fig. 3. Septae in vessels. The arrows indicate septae. (A-B) Miconia albicans. (C) Miconia chamissois. (D) Miconia fallax. Bars $=(A, C) 50 \mu \mathrm{m} ;(B, D) 25 \mu \mathrm{m}$.

$73 \times 30 \mathrm{~mm}(300 \times 300 \mathrm{DPI})$ 


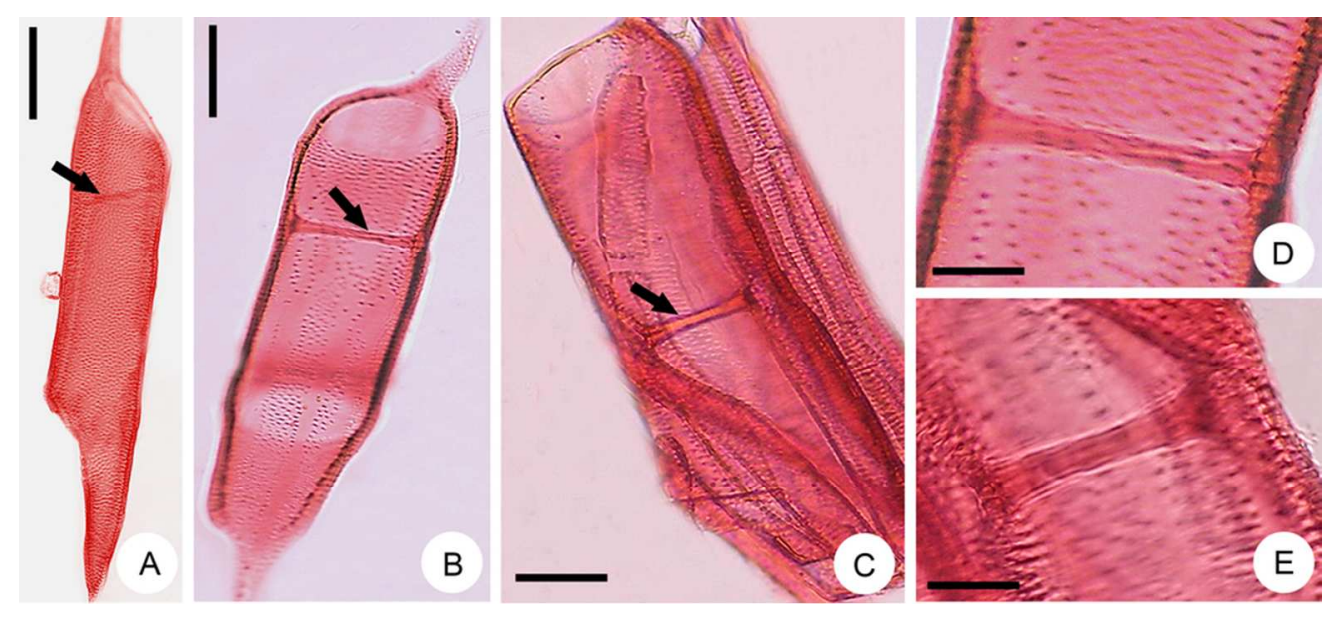

Fig. 4. Trabeculae in vessel elements in Melastomataceae species. Macerated wood. (A) Miconia albicans. (B-D) Miconia fallax. (E) Miconia ligustroides. The arrows indicate trabeculae. Bars $=(A-C) 50 \mu \mathrm{m}$; $(D-E) 25$ $\mu \mathrm{m}$.

$86 \times 39 \mathrm{~mm}(300 \times 300$ DPI $)$ 

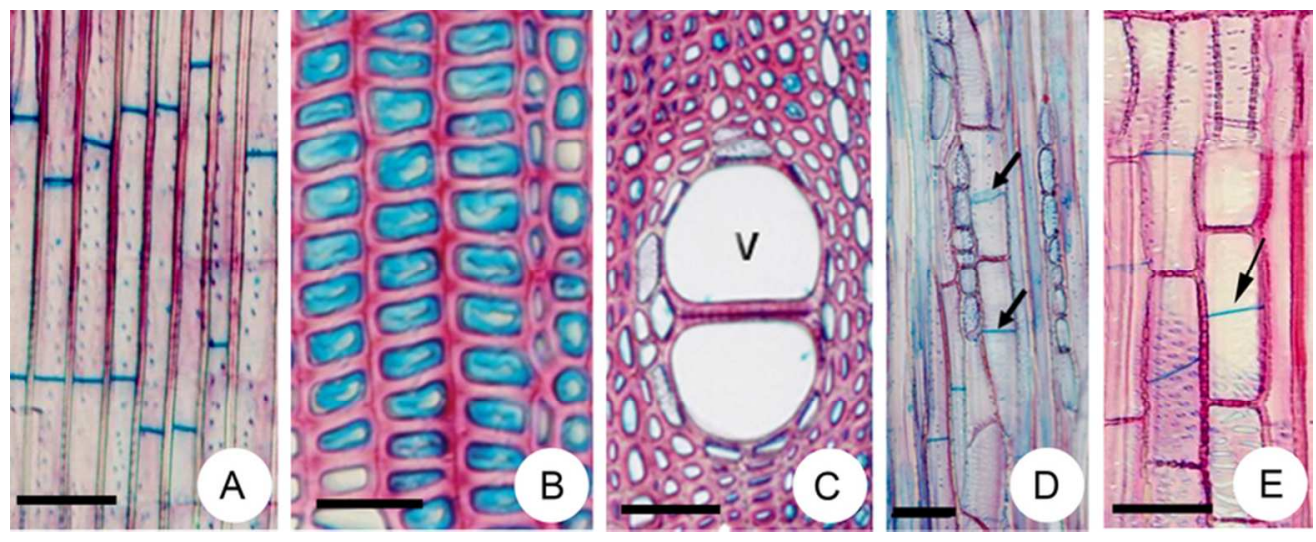

Fig. 5. Wood features of Melastomataceae species. (A) Simple to minutely bordered pits in radial wall and septate fibers in Miconia albicans. (B) Gelatinous fibers in Rhynchanthera dichotoma. (C) Scanty axial parenchyma around vessel (V) in Miconia albicans. (D-E) Septae (arrows) in axial parenchyma. (D) Miconia

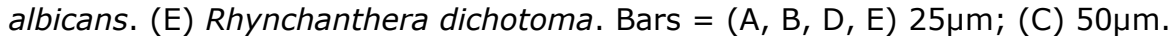

$71 \times 28 \mathrm{~mm}(300 \times 300$ DPI $)$ 

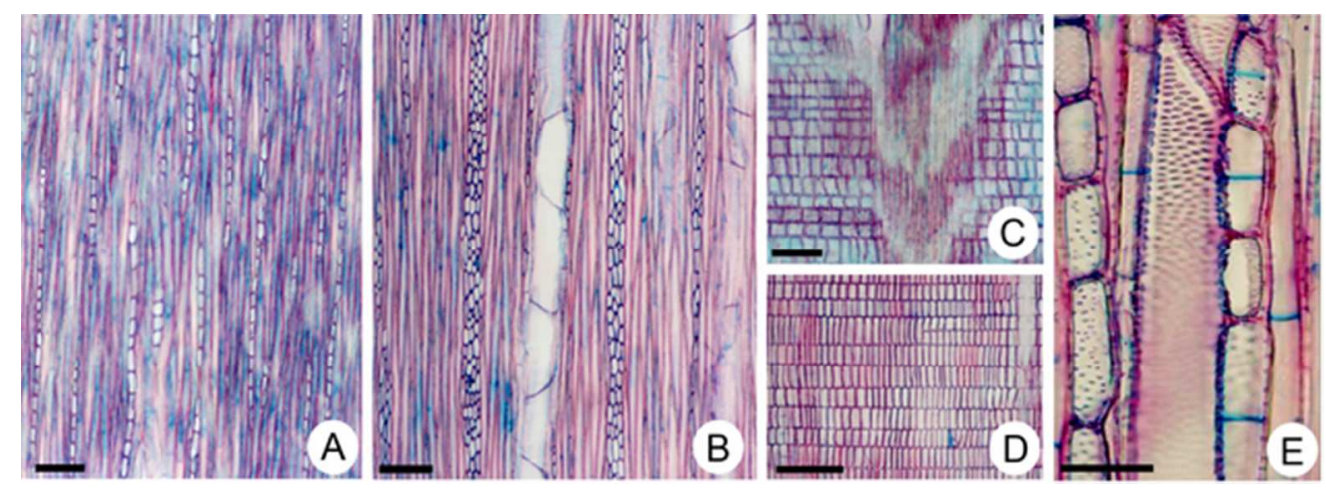

Fig. 6. Rays of Melastomataceae species. (A-B) Tangential sections. (A) Rays exclusively uniseriate in Miconia albicans. (B) Ray 1-3 cells width in Microlepis oleaefolia. (C-D) Heterocellular rays in radial sections. (C) Procumbent, square and upright cells intermixed in Miconia albicans. (D) Square and upright cells in Miconia fallax. (E) Septae in ray cells and fiber in Miconia chamissois in tangential section. Bars $=(A, B, D)$ $200 \mu \mathrm{m}$; (C) $100 \mu \mathrm{m}$; (E) $50 \mu \mathrm{m}$.

$53 \times 19 \mathrm{~mm}(300 \times 300 \mathrm{DPI})$ 

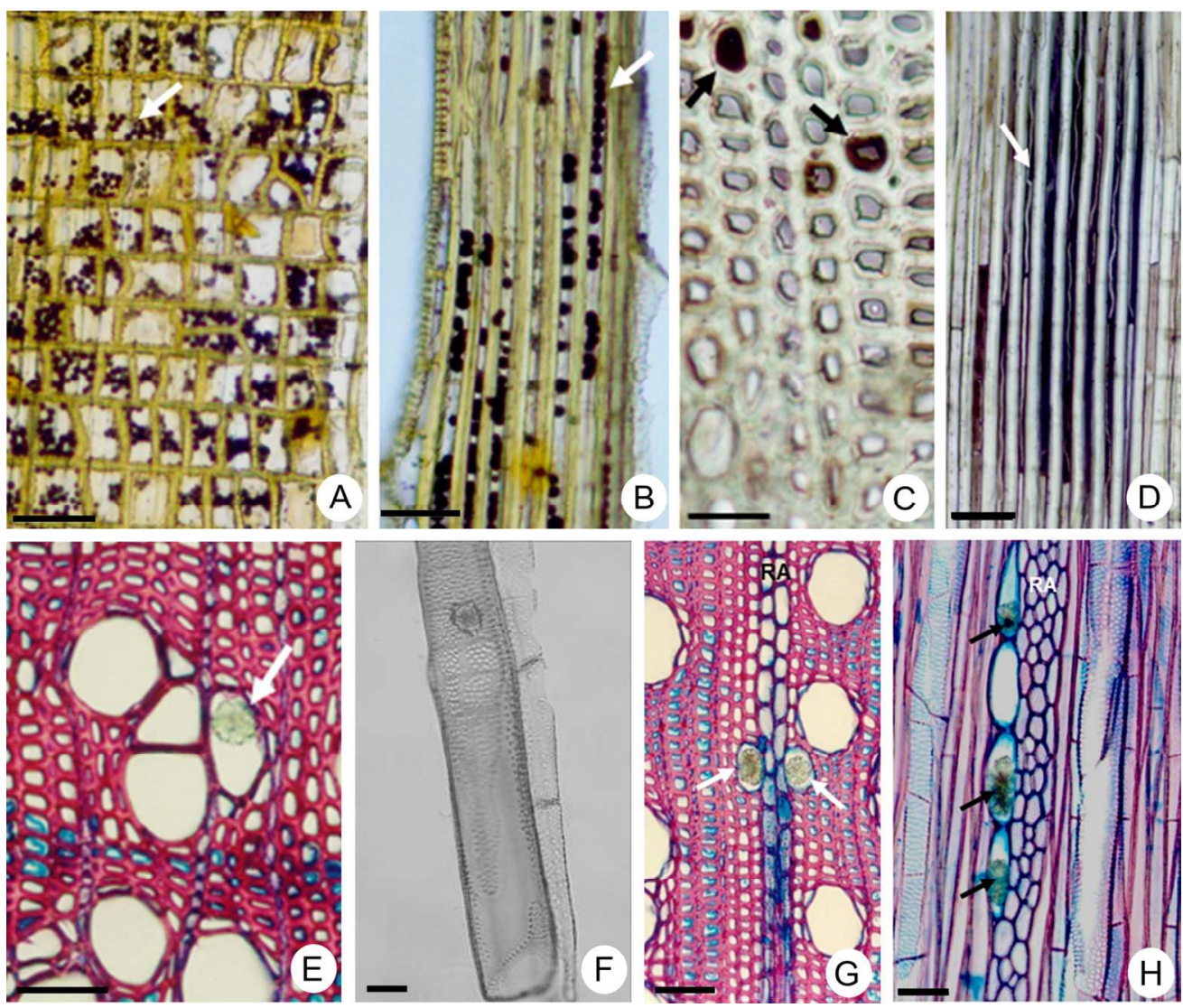

Fig. 7. Inclusions in wood cells of Melastomataceae species. (A-B) Starch grains (arrows) in wood cells of Miconia albicans in radial and tangential section, respectively. (A) In ray cells (B) In septate fibers. (C-D) Phenolic compounds (arrows) inside septate fibers of Miconia albicans in transverse and radial section, respectively. (E-H) Druses (arrows) in wood cells. (E-F) Inside vessel element in Miconia chamissois in transverse section, and in dissociate cell, respectively. (G-H) In the margin of the ray in Microlepis oleaefolia in transverse and tangential section, respectively. $R A=$ ray. Bars $=(A, B, D, E, G, H) 50 \mu \mathrm{m}$; (C) $25 \mu \mathrm{m}$;

(F) $100 \mu \mathrm{m}$.

$143 \times 121 \mathrm{~mm}(300 \times 300 \mathrm{DPI})$ 


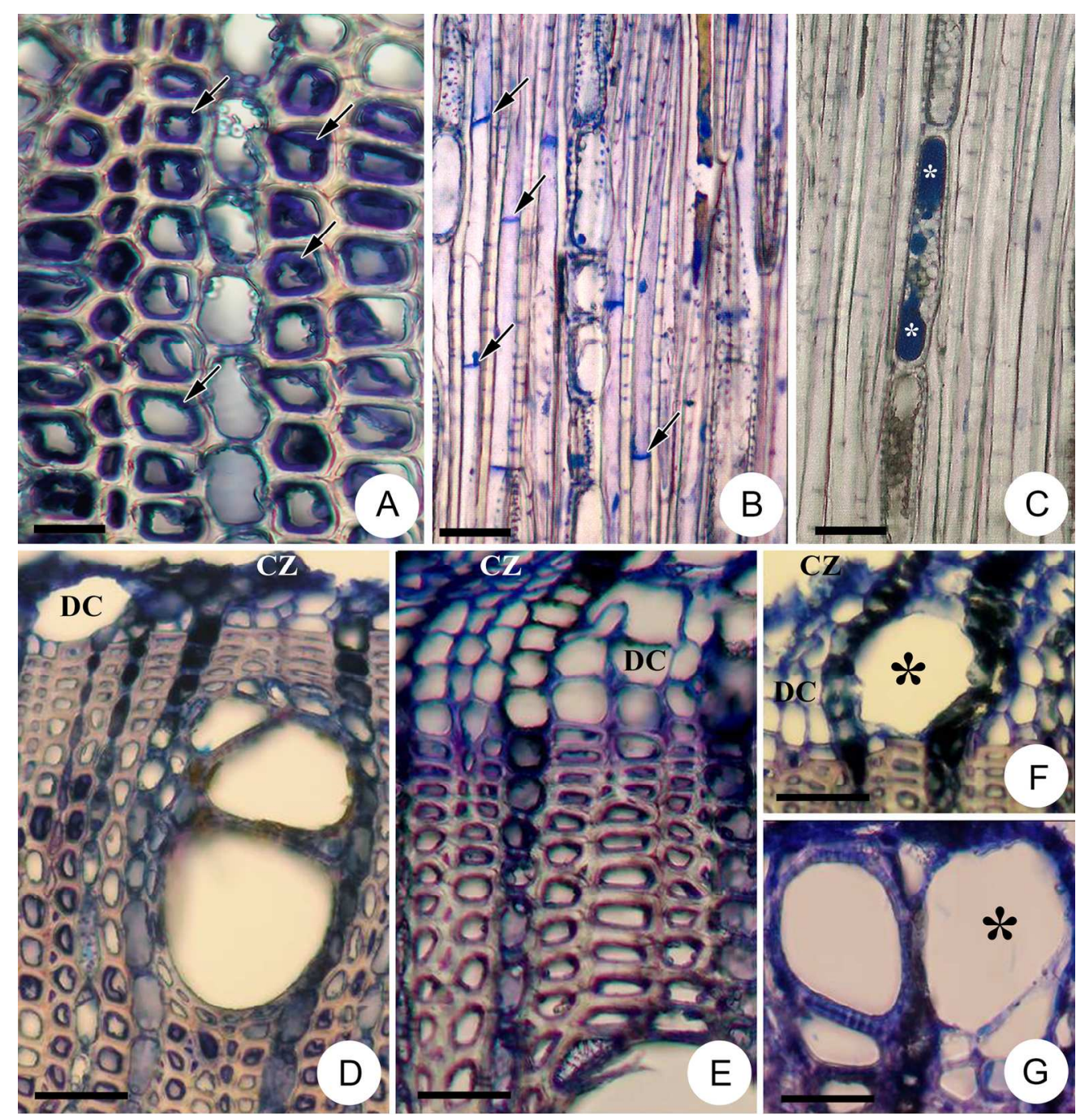

Fig. 8. Spot-test using chrome azurol-S reagent to detect aluminium accumulation, blue color for positive response. (A) In the inner wall of gelatinous fibers (arrows) of Miconia albicans. (B) In the septa of fibers (arrows) of Miconia ligustroides. (C) In the vacuoles of ray cells (asterisks) of Miconia ligustroides. (D-G) In the cambial cell walls and in the walls of differentiating cells. (D) Miconia albicans. (E) Miconia fallax. (F-G) Miconia ligustroides. $\mathrm{CZ}=$ cambial zone; $\mathrm{DC}=$ differentiating xylem cells; $"=$ differentiating vessels. $\mathrm{Bars}=$ $(A, E) 25 \mu \mathrm{m} ;(B, D, F) 100 \mu \mathrm{m} ;(C, G) 50 \mu \mathrm{m}$.

$166 \times 173 \mathrm{~mm}(300 \times 300 \mathrm{DPI})$ 